\title{
Educated Females Participation In Labor Market: The Role Of Structural Barriers
}

\author{
Sidra Maqsood \\ Academics and Research \\ Punjab Higher Education Commission
}

Fauzia Maqsood

Faculty of Social Sciences

University of Gujrat

\begin{abstract}
Females' proportion is increasing at higher levels of education in Pakistan but educated female's employment is not increasing in consonance with their level of education. The main purpose of the present research is to explore the structural barriers of educated females regarding their participation in labor market. A sample of 251 female respondents was selected from University of Gujrat through stratified random sampling technique to conduct survey. A well-structured questionnaire was administered by the researcher to collect data from the respondents. Logistic regression was applied to examine independent effect of variables. To find out significance of various independent variables, dependent variable was cross examined by using chi- square method. Findings of Logistic regression revealed that structural factors were 3.3 times more likely to exhibit favorable attitude towards female employment, whereas respondents with highly supportive family's normative factors were 2.9 times more likely to have favorable attitude towards female employment. The study suggested that there is still need to do more studies as well as large scale cross sectional house hold national surveys on this topic and there should be a mechanism to develop awareness campaign strategies to create awareness by using different channels including media, NGOs, and some other concerned departments to minimize structural factors and enhance female labor force participation.
\end{abstract}

Keywords; Educated Females, Participation, Labor Market, Structure, Barriers.

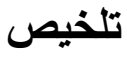

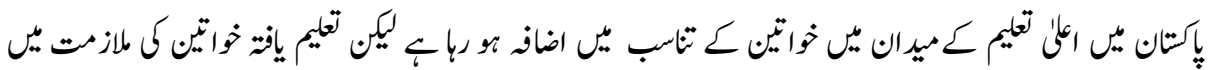

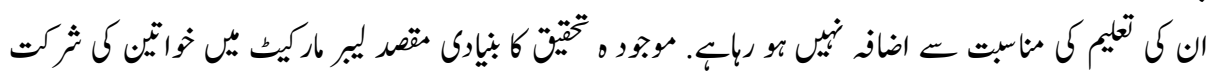

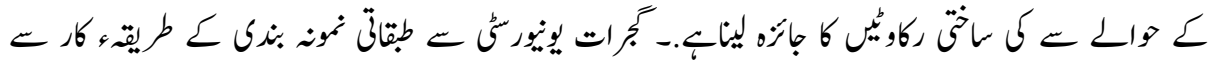

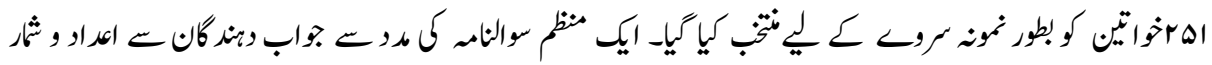

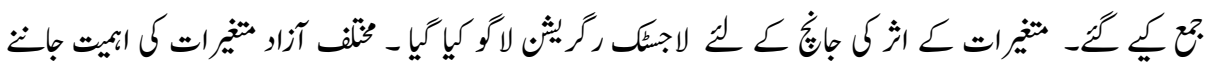

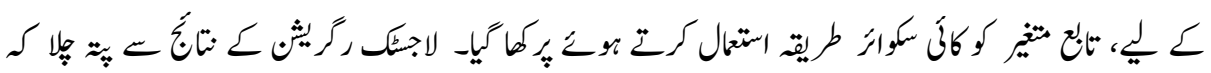




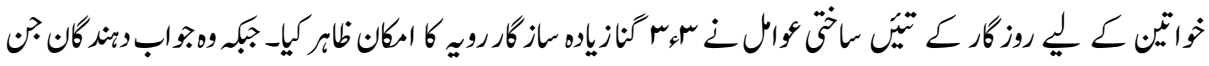

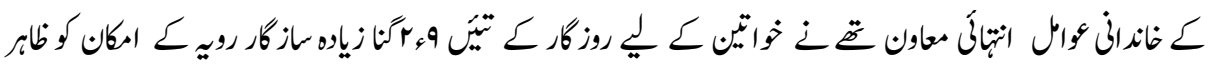

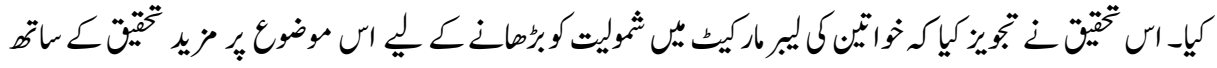

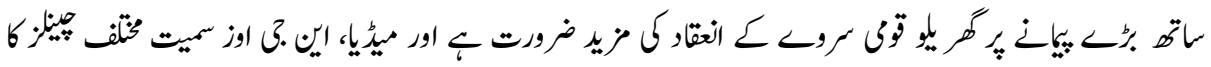

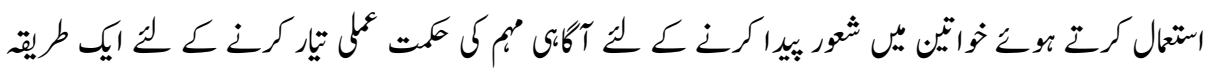

$$
\begin{aligned}
& \text { كر ابناسنكان }
\end{aligned}
$$

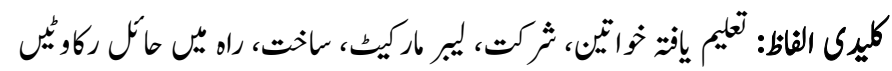

\section{Introduction}

There is a contradictory phenomenon in Pakistani society between female's education rate and participation of educated females in labor market. In Pakistan an increasing number of females are acquiring education and their proportion is further increasing at higher levels of education. The enrolment ratio of female in higher education increased from $36.96 \%$ to $46.3 \%$; while male enrolment ratio decreased from $63.04 \%$ to $53.7 \%$ over the time period 2001 to 2008 . Female's employment is not increasing in consonance with their level of education, which is on rise nowadays. A declining trend in the salaried and self-employed females during 2000 to 2008; whereas the percentage of women working in family farms and homesteads has steadily increased from $49.9 \%$ in 2000 to $63.2 \%$ during the same period. Women's participation in labor market with higher education levels (Intermediate, Bachelors and above) has decreased during 1990-1991 to 2003-2004. Both in rural and urban areas, the percentage of educated women's participation in the labor force have declined during 1990-91 to 2003-2004 (FBS, 2009).

Civil society and state are all advocating empowerment of women through education and creation of job opportunities as education along with financial health are considered as key factors in empowering women all over the world. Females' participation in labor market not only promise economic benefits for country but also viewed as an indicator of declining discrimination and increasing empowerment of females (Karshenas \& Moghadam (2001); Khattak (2001); Fogli \& Veldkamp 2010).

Structural and Socio-cultural barriers have been identified as the most inhibiting factors in the attainment of female's employment in Pakistan. In every society marked by gender segregation, males, by and large, are considered as the sole agent for bread winners and females are confined to merely household chores as their primary responsibilities. The meaning of "work" is coded with gendered expectations that men are the "breadwinners" and that women's work is properly located in the unpaid voluntary sector or home. 
(Teghtsoonian, 1995; Forssen \& Hakovirta, 2000; Macionis, 2009). Females in all over the world contribute to the majority of household labor force and maintain their primary responsibility for child bearing. Household responsibilities and child care are traditionally considered to be in the domain of female duties that do inhibit them to participate in labor market (Alkan, 1995; Aran, et al., 2009; Dayioglu and Kirdar, 2009; Taymaz, 2009). Moreover, Lokshin et al. 2000. noted that economic incentives in the form of child-care centers by the public sector have a powerful effect on the work behavior of women.

The cultural norms and traditions in Pakistan have generated the circumstances, where males and females have been confined into specific family roles with the females accepting most of their family responsibilities without any agitation (UNICEF, 2006).

While discussing barriers to female labor force participation, we cannot ignore structural difficulties being faced by females to find decent work. The concept of decent work was introduced by International Labor Conference (ILO) in 1999. ILO defined "decent work" as a work which provides freedom, equality, security and human dignity to employees, irrespective of their gender i.e. male or female (Freiler et al. 2001; Ghai, 2003; GüvenLisaniler 2003; ILO, 1999). In Pakistani society, female's access to a decent work is very limited. In the patriarchal structure prevalent in Pakistani society, it is still a common belief that females are not suited for the professions which involve management, risk taking and leadership qualities. This belief has been imbibed both in male and female through the continuous process of socialization originated in the institution of family.

Moreover, females attainted their graduate degrees mostly in 'softer' disciplines such as arts, humanities, languages, literature and education etc. Only college degree in these disciplines is not enough to get a decent job in today's globalizing and market-oriented society. This deficit of skill-oriented degree is not in consonance with modern needs nowadays, because current global economy as well as information society demands skillful labor having professional qualifications in thriving disciplines like information technology, business management, engineering etc. Studies done in past also highlight this fact that knowledge about computer and IT has become an essential requirement for many jobs and it is also associated with high wages (Autor et al., 1998). Kottegoda, (1991) also noted that low participation of females in education based on is a potential barrier for them to participate in labor market. Further, this limitation restricts females only to low-paid jobs. Gender discrimination at the labor market has a significant role in limiting female labor force participation. It is estimated by the United Nations Economic and Social Commission for Asia and the Pacific (UNESCAP, 2007) that it costs up to USD 80 billion for Asia per annum owing to restrictions imposed on women to participate in labor market and access to schooling. Females also face difficulties to get long-term contract jobs, because they usually quit job after marriage. For example, it is 
reported that men's labor force participation rates do vary, for example as they grow old or get married, they show less variations than females (Neft and Levine 1997).

The literature in Pakistan, particularly studies on the impact of structural factors to educated females' labor force participation is limited. There is a need to plan and carry out studies that will document the structural barriers to women's participation in labor market. The findings of such studies can contribute greatly to public policies and programs that would facilitate educated women's participation in the labor market.

\section{Objectives of the Study}

- To analyze the socio-economic characteristics of the respondents

- To explore the normative and structural barriers to educated female participation in labor market

- To suggest policy measures to enhance female labor force participation

\section{Material and Methods}

In the present study Survey method was used to obtain information from graduating female students of BS (Hons) and Masters at University of Gujrat. Researcher collected sampling frame from the concerned office of university and population was comprised on 35000 elements. By using Yamni (1967) sample size determination formula, a sample size of 251 respondents was selected through proportionate random sampling technique on the basis of elements characteristics. A detailed Individual Questionnaire was developed for eliciting information, views and opinions about female participation in the labor market and their own plans about working after graduation from the students who were about to enter the labor market. The measurement instrument was pre-tested from 25 respondents. Further, researcher used Statistical Package for Social Sciences (SPSS) to draw results and conclusion. Since dependent variable of present study was categorical in nature having two categories favorable and unfavorable attitude towards female participation in labor market. Therefore, logistic regression seemed suitable option to examine independent effects of various independent variables. To find out significance of different / various independent variables, dependent variable was cross examined by using chi- square method.

\section{Results and Discussions}

Section 1.1 in Table 1 depicts the age group of the respondents and only small proportion $(6.7 \%)$ of the respondents was belonging to age bracket of 25 to 29 years. Data indicates that majority $(93.2 \%)$ of the respondents are in the age group 20 to 24 years. Section 1.2 describes the father's occupation of the respondents. Major occupation of father as 
indicated in above table is businessman. The reason to ask this question is to develop a socio-economic profile of the respondents' family. Secondly, to see if father's occupation influences differently the choice of female's joining labor market. Data indicates that majority $(43.5 \%)$ of respondents' father's occupation in business and second large category is professional $(14.2 \%)$.

Table: 1

Socio-economic characteristics of the respondents

\begin{tabular}{|l|c|c|l|c|c|}
\hline 1.1Age Bracket of the Respondents (Yr.) & 1.3 Current Enrolled Program \\
\hline Category & Frequency & Percentage & \multicolumn{1}{|c|}{ Category } & Frequency & Percentage \\
\hline $20-24$ & 234 & 92.5 & BBA/BS Hons & 157 & 62.1 \\
\hline $25-29$ & 17 & 06.7 & MA/MSc/MBA & 94 & 37.2 \\
\hline Total & 251 & 99.2 & Total & 251 & 99.2 \\
\hline 1.2 Father's Occupation & & 1.4 Father's Monthly Income (Rs.) \\
\hline Category & Frequency & Percentage & Category & Frequency & Percentage \\
\hline Teacher & 22 & 8.8 & Less than 10,000 & 9 & 3.6 \\
\hline Official & 28 & 11.2 & $10,000-20,000$ & 39 & 15.5 \\
\hline Businessman & 101 & 40.2 & $20,001-30,000$ & 55 & 21.9 \\
\hline Professional & 33 & 13.1 & $30,001-40,000$ & 41 & 16.3 \\
\hline Farming & 29 & 11.6 & $40,001-50,000$ & 34 & 13.5 \\
\hline Skilled Labour & 19 & 07.6 & More than 50,000 & 52 & 20.7 \\
\hline Total & 232 & 92.4 & Total & 230 & 91.6 \\
\hline No response & 19 & 07.6 & No Response & 21 & 08.4 \\
\hline Total & 251 & 100.0 & Total & 251 & 100.0 \\
\hline
\end{tabular}

Data in above table describes the distribution of respondents with respect to their degree level i-e BS and MA. Table indicates that $62.5 \%$ respondents were from BS and $37.5 \%$ were from MA. Last portion of the table 1 shows father's monthly income of the respondents. Around $41 \%$ of respondents' fathers' income ranges from 10,000 to 30,000 and around $33 \%$ range from 30,000 to 50,000 and about $23 \%$ had income 50,000 or more per month. It seems this income distribution is comparatively higher income groups. This information was asked to develop socio- economic profile of respondents' family.

Data regarding barriers to participation of females is gathered through asking about different structural and cultural barriers. Respondents' opinion on participation of married females in labor market was also sought; similarly their views whether married females could balance work and family life. Data on the above mentioned variables were collected to obtained respondents views and information about the structural and/or cultural barriers that hinder participation of females in labor market. 
Table: 2

Respondent's views

\begin{tabular}{|l|c|c|}
\hline \multicolumn{1}{|c|}{ 2.1 Regarding Participation of Females in the Labor Market } \\
\hline Favorable & Frequency & Valid Percentage \\
\hline Unfavorable & 230 & 91.6 \\
\hline Total & 21 & 08.4 \\
\hline 2.2 Reasons for Preferred Jobs for Educated Females \\
\hline Teaching & 70 & 100.0 \\
\hline Doctors & 11 & 27.9 \\
\hline Nursing & 02 & 0.4 \\
\hline Office Jobs & 25 & 10.0 \\
\hline Any reasonable job & 132 & 52.6 \\
\hline Total & 240 & 95.6 \\
\hline No response & 11 & 4.4 \\
\hline Total & 251 & 100.0 \\
\hline 2.3 About Married Females' Joining Labor Market & 64.5 \\
\hline Favorable & 162 & 35.3 \\
\hline Un favorable & 89 & 100.0 \\
\hline Total & 251 & 72.5 \\
\hline 2.4 On Working Women's Ability to Balance Work and Family \\
\hline Can balance & 182 \\
\hline Can't balance & 69 & 27.5 \\
\hline Total & 251 & 100.0 \\
\hline
\end{tabular}

Table 2 describes the respondents' attitude about female participation in the labor market. A large majority of respondents $(92 \%)$ have a favorable attitude towards female participation in the labor market. The data indicates that respondents are of the view that educated females should join labor market. The table also shows the respondents' perception about suitable jobs for females. Usually, it is argued that females mostly prefer jobs like teaching and health profession but in above table $55.0 \%$ responses in 'any reasonable job' indicate that they are willing to join any reasonable job according to their skills. It shows flexibility regarding job choices and they are not restricted by cultural norms and values to opt only teaching as profession. So if society provides reasonable and appropriate jobs to females than the ratio of females participation can be increased remarkably.

To understand the views of respondents' if the women should join the labor market after getting married a specific question was asked to all the respondents. The idea was to study if marital status changes the attitude and factors of married women regarding 
participation in labor market. The data in table 2 shows that only $64.5 \%$ of the respondents are of the view that married females should also join labor market. Whereas, this percentage was also $92 \%$ when respondents were asked if educated women should join the labor market. It seems marital status does make a difference. It could be argued that after getting married the responsibility of the family such as house hold chores, raising children dampens the labor force participation. However, as per the qualitative data as described in chapter\# indicate if the society provides support system at home and in work places married females may be able to join labor market.

Section 2.4 highlights respondents' perception about working females' ability to balance their work and household responsibilities. A significant percentage of respondents $72.5 \%$ are of the view that they can balance their work and household responsibilities. It shows their willingness and favorable attitude towards joining labor market. These students are expected to enter in labor market. The above data suggest that our respondents feel positive about joining labor market and attaining a balance in work and household responsibilities. So it leads to the argument that traditional gender roles are changing now but it needs sufficient structural changes in society to be implemented.

Table: 3

Respondent's reasons

\begin{tabular}{|l|c|c|}
\hline \multicolumn{1}{|c|}{ 3.1 Why Mostly Educated Females do not Join Labor Market } \\
\hline \multicolumn{1}{|c|}{ Reasons } & Frequency & Percentage \\
\hline Females are not allowed to work & 45 & 17.9 \\
\hline Females don't feel comfortable to work & 28 & 11.2 \\
\hline $\begin{array}{l}\text { Due to family responsibilities such as taking } \\
\text { care of home and children }\end{array}$ & 86 & 34.0 \\
\hline Due to insecure environment & 72 & 28.7 \\
\hline Due to non-availability of appropriate job & 20 & 08.0 \\
\hline Total & 251 & 100.0 \\
\hline 3.2 Women's Work may affect Family Life Negatively & 43.0 \\
\hline May affect negatively & 108 & 57.0 \\
\hline May not affect negatively & 143 & 100 \\
\hline Total & 251 & 71.3 \\
\hline 3.3 Travelling Alone to Workplace & 179 & 28.7 \\
\hline Yes & 72 & 100.0 \\
\hline No & 251 & \\
\hline Total & & \\
\hline
\end{tabular}

Table 3 indicates the respondents' perception regarding the factors responsible for low participation of educated females in labor market. The response "females are not allowed to work" (17.9\%) represent a cultural barrier to females participating in labor market. The reason was because females could not get permission due to family restrictions and 
traditions. The other response "females don't feel comfortable to work'(\%), ' due to family responsibilities such as taking care of home and children due to insecure environment' and 'due to non-availability of appropriate jobs' were operationalized as structural barriers in the present research. It can be argued that females don't feel comfortable due to insecure environment at workplaces. So it is the structural issue of employing institution that they cannot provide conducive work environment for females. Structure of the family is also indicated as one of the major barrier to females' employment in the above table having $34.0 \%$. It can be argued that despite having permission of family, because of dual responsibility of at home and at workplace females could not join labor market.

Section 3.2 shows the respondents' opinion regarding negative effects of women work on family life. Here, again majority $(57.0 \%)$ of the respondents are of the view that working women's can balance their work and family life and it may not affect family life negatively. It supports the above discussed argument that females can balance their work and family life.

It was asked by respondents that if they have to travel alone to their workplace, would they be able to go alone. Data in table (section 3.3) indicates that majority (71.3\%) of the respondents are of the view that they can travel alone to their workplace if they join labor market. While only $28.7 \%$ respondents said that they cannot go alone to their workplace. This finding seems to suggest that family orientation towards girls' mobility is not conservative. Moreover girls are socializing in a way that they can travel alone. But again these are the views of those girls who are not yet entered in labor market. It might be possible if social structure will fail to provide security to females; these females would also not join labor market.

Table: 4

Favorable attitude towards female labor force participation by fathers' income

\begin{tabular}{|c|c|c|c|c|c|c|c|c|c|}
\hline & \multicolumn{6}{|c|}{ Father's Monthly Income (RS.) } & \multirow[t]{2}{*}{ Total } \\
\hline & & & $\begin{array}{c}\text { Less than } \\
10,000\end{array}$ & $\begin{array}{c}10,000 \\
-20,000\end{array}$ & \begin{tabular}{|c|}
20,001 \\
$-30,000$
\end{tabular} & $\begin{array}{c}30,001- \\
40,000\end{array}$ & $\begin{array}{c}40,001- \\
50,000\end{array}$ & $\begin{array}{c}\text { More than } \\
50,000\end{array}$ & \\
\hline \multirow{4}{*}{$\begin{array}{l}\text { Favorable } \\
\text { attitude }\end{array}$} & \multirow{2}{*}{$\begin{array}{c}\text { Not } \\
\text { Favorable }\end{array}$} & No. & 6 & 8 & 20 & 13 & 10 & 10 & 67 \\
\hline & & $\%$ & $66.7 \%$ & $20.5 \%$ & $36.4 \%$ & $31.7 \%$ & $29.4 \%$ & $19.2 \%$ & $29.1 \%$ \\
\hline & \multirow[t]{2}{*}{ Favorable } & No. & 3 & 31 & 35 & 28 & 24 & 42 & 163 \\
\hline & & $\%$ & $33.3 \%$ & $79.5 \%$ & $63.6 \%$ & $68.3 \%$ & $70.6 \%$ & $80.8 \%$ & $70.9 \%$ \\
\hline \multirow{2}{*}{\multicolumn{2}{|c|}{ Total }} & No. & 9 & 39 & 55 & 41 & 34 & 52 & 230 \\
\hline & & $\%$ & $100.0 \%$ & $100.0 \%$ & $100.0 \%$ & $100.0 \%$ & $100.0 \%$ & $100.0 \%$ & $100.0 \%$ \\
\hline
\end{tabular}

Income is supposed to influence orientations of individuals. In the same vein income of respondents' father was taken as independent variable to find if father's income influences respondents' attitude towards female employment. Compound frequency distribution provides that majority of respondents $(80.8 \%)$ are those whose father's income was more than 50,000 Rs. and these respondents had favorable attitude towards female employment compared to $33.3 \%$ respondents whose father's income was less than 10,000 Rs. and they had favorable attitude towards female employment. Further chi square value $(.042<.05)$ 
strengthens this assumption that income does influence attitude of respondents. The findings of results could be strengthened by the argument that with father's high income females may get a chance to expose to those groups that support egalitarian gender profile or high socio economic status. It is generally observed that individuals with high socio economic status give women more space to utilize their potential.

Table: 5

Favorable attitude towards female employment by father's work status

\begin{tabular}{|l|c|c|c|c|c|}
\hline \multicolumn{2}{|c|}{} & \multicolumn{2}{c|}{ Father's working status } & Total \\
\hline \multirow{2}{|c|}{$\begin{array}{l}\text { Favorable } \\
\text { attitude }\end{array}$} & \multirow{2}{*}{ No } & No. & Working & Not-working & \\
\cline { 3 - 6 } & & $\%$ & $28.8 \%$ & 1 & 68 \\
\cline { 3 - 6 } & \multirow{2}{*}{ Yes } & No. & 166 & 15 & 181 \\
\cline { 3 - 6 } & & $\%$ & $71.2 \%$ & $93.8 \%$ & $72.7 \%$ \\
\hline \multirow{2}{*}{ Total } & No. & 233 & 16 & 249 \\
\cline { 3 - 6 } & & $\%$ & $100.0 \%$ & $100.0 \%$ & $100.0 \%$ \\
\hline
\end{tabular}

Working status of respondents' father was another important factor in determining the attitude of females towards female's employment. Keeping in view this assumption working status of respondent's father was taken and contingency table was constructed with attitude towards female employment. Compound frequency distribution suggest that $93.8 \%$ of respondents were those whose father were not working and they had favorable attitude towards female employment compared with $71.2 \%$ of respondents whose fathers were working and they had favorable attitude towards female employment. This finding should be read with caution because overall the number of respondents' father with nonworking status was very low (16 out of 249). Therefore, fisher exact test was applied to statistically test the association. Value of statistical test was .038 less than .05, therefore, association between working status of father and respondent's attitude towards female employment was significant.

Table: 6

Favorable attitude towards females' employment by demographic, structural and normative environment

\begin{tabular}{|l|c|c|c|c|}
\hline \multirow{2}{*}{ Variables } & \multirow{2}{*}{ P Value } & \multirow{2}{*}{ Odds Ratio } & \multicolumn{2}{c|}{ 95\% CI } \\
\cline { 3 - 5 } & & & Lower & Upper \\
\hline Age & .396 & .605 & .190 & 1.931 \\
\hline Place of residence & .113 & 2.428 & .810 & 7.278 \\
\hline Place of growing up & .918 & 1.058 & .363 & 3.086 \\
\hline Father's Income & .091 & 1.217 & .969 & 1.527 \\
\hline Structural Environment & .002 & 3.390 & 1.552 & 7.403 \\
\hline Normative Environment & .007 & 2.928 & 1.347 & 6.363 \\
\hline
\end{tabular}

Hosmer and Lame show .829 
Logistic regression analysis was conducted to find the net effect of various factors that affect favorable attitude towards female employment. Amongst these factors age of the respondents, their place of residence, place of growing up and their father's income were not significantly affecting favorable attitude towards female employment. Results indicate that respondents who had highly supportive structural environment were 3.3 times more likely to develop favorable attitude towards female employment, whereas respondents with highly supportive normative environment are 2.9 times more likely to have favorable attitude towards female employment.

The results seem to indicate that structural environment is more powerful in determining attitude towards female employment compared to normative environment. Structural environment was measured by taking into account distance to work place, availability of job in some other city other than the city of residence of respondents, family's permission to work in some other city and flexibility of working hours. Given the traditional set up of Pakistani society, these factors seem to be very sensitive because they are concerned with the security issue of females as well as reputation of their family. Results indicate that if these factors are less severe for females there are more chances that they will have positive attitude towards female employment. Similarly normative environment was measured by taking into account working with male colleague, family's permission to work with male colleague, acknowledging contribution of working women's towards family income. Results indicated that supportive normative environment leads towards favorable attitude towards female employment.

\section{Conclusions}

Female' students had plans to join labor market and their families were also had favorable orientation towards females' employment. Although these were just opinions of females' students about their future plans but this information leads to assume that there are chances of increase in the rate of educated females' participation in labor market. With reference to structural barriers to female employment, majority of the respondents were of the view that non-availability of jobs, low wages, distance to workplace, access to transport were the main hindering factors. The study suggested that there is still need to do more studies as well as large scale cross sectional house hold national surveys on this topic and there should be a mechanism to develop awareness campaign strategies to create awareness regarding structural barriers of female labor force participation.

\section{References}

Aran, M., Capar S., M., D. Husamoglu, S. \& Uraz A. (2009). Recent Trends in Female Labor Force Participation in Turkey. Ankara: World Bank and Turkey State Planning Organization. 
Autor, D. H., Lawrence F. K. \& Alan B. K. (1998). Computing Equality; Have Computers Changed the Labour Market? Quarterly Journal of Economics, vol.113:4, pp.1169-213.

Alkan, D. (1995). Women's Employment and Income Distribution by Gender in Turkey Unpublished Master's Thesis. Middle East Technical University.

Dayioglu, M. \& Kirdar M. G. (2009). Determinants of and Trends in Labor Force Participation of Women in Turkey. Ankara: Middle Eastern Technical University.

Fogli, A. \& Veldkamp, L. (2010). Nature or Nurture? Learning and the Geography of Female Labor Force Participation. Journal of the Econometric Society, vol.79:4, pp.103-1138.

Freiler, Christa, Stairs, F. \& Kitchen, B. (2001). Mothers as Earners, Mothers as Carers: Responsibility for Children, Social Policy and the Tax System. Ottawa: Status of Women Canada.

Forssén, K. \& Hakovirta M. (2000). Family Policy, Work Incentives and Employment of Mothers: Findings from the Luxembourg Income Study. Helsinki: International Social Security Association.

Federal Bureau of Statistics, Labour Force Survey. (2007-09). Government of Pakistan, Islamabad. http://app.hec.gov.pk/UniversityFinal2/RegionUniversity.aspx accessed on 03.09.2011

Güven-Lisaniler F. (2003). Assesing the Status of Women: A Step toward Gender Equality. Famagusta: Turkish Cypriot University Women's Association Publication. (Also published in Turkish as Kadının Statüsünün Tesbiti: Kadın Erkek Eşitliğine Doğru Bir Adım)

Ghai, D. (2003). Decent Work: Concept and Indicators, International Labour Review, vol.142:2, International Labour Organization.

ILO. (1999). Report of the Director- General: Decent Work, $87^{\text {th }}$ Session, Geneva.

Karshenas, M. \& Moghadam, V. (2001). Female Labour Force Participation and Economic Adjustment in the MENA Region. Research in Middle East Economics, vol.4, pp.51-74. 
Khattak, S. (2001). Women, Work and Empowerment, in Asad Sayeed and Saba Gul Khattak, eds. Women's Work and Empowerment Issues in an Era of Economic Liberalization: A Case Study of Pakistan's Urban Manufacturing Sector. Islamabad: Pakistan Institute of Labor Education \& Research (PILER) and Sustainable Development Policy Institute (SDPI). pp.65-87.

Kottegoda, S. (1991). Women in the Informal Sector- Working Paper No.2", Colombo: Centre for Women's Research.

Lokshin, M. M., Glinskaya E. \& Garcial M. (2000). The Effects of Early Childhood Development Programs on Women Labor Force Participation and Older Children Schooling in Kenya. Policy Research Working Paper 2376. The World Bank: Washington D.C.

Macionis, J. J. (2009). Sociology, Pearson Education, Inc. India: Dorling Kindersley Publishing Inc.

Neft, Naomi. \& Anne D. Levine. (1997). Where Women Stand: An International Report on the Status of Women in 140 Countries. New York: Random House.

Taymaz, E. (2009). Growth, Employment, Skills and Female Labor Force. Economic Research Center, Middle East Technical University.

Teghtsoonian, K. (1995). Work and/or Motherhood: The Ideological Construction of Women's Options in Canadian Child Care Policy Debates. Canadian Journal of Women and the Law, vol.8, pp.411-439.

UNESCAP. (2007). Economic and Social Survey of Asia and the Pacific 2007-Surging Ahead in Uncertain Times. UNESCAP, United Nations: New York.

UNICEF. (2006). The State of the World's Children. South Asian ed. New York: UNICEF Women and Children.

Yamane, T. (1967). Statistics: An Introductory Analysis, 2nd Ed. New York: Harper and Row.

Sidra Maqsood is Director, Academics and Research, Punjab Higher Education Commission, Pakistan.

Prof. Dr. Fauzia Maqsood is Dean, Faculty of Social Sciences, University of Gujrat, Pakistan. 